\title{
Tropical Concepts in the Re-design of the Banyuwedang Hot Spring Tourism Object Master Plan
}

\author{
I Kadek Merta Wijaya ${ }^{1}$, I Gusti Agung Putu Eryani ${ }^{2}$, Ni Wayan Nurwarsih ${ }^{3}$ \\ \{amritavijaya@gmail.com\} \\ ${ }^{1,3}$ Department of Architecture, Faculty of Engineering and Planning, Warmadewa University, Denpasar \\ ${ }^{2}$ Department of Civil Engineering, Faculty of Engineering and Planning, Warmadewa University, \\ Denpasar
}

\begin{abstract}
Architecture and tourism tend to influence each other in spatial planning. Therefore, natural resources need to be adequately considered while as a sustainable part of tourism areas. This conception is applied in the redesign of the Banyuwedang Hot Spring Tourism Objects, where the natural potential possessed acts as a site of attraction. Hot springs, mangrove forests and temple architecture are important aspects that need to be considered in developing bathing in these areas. These facilities are embodied in accommodations that supports tourist, however, their presence have a negative impact on the Banyuwedang Hot Spring Tourism area. The purpose of this paper is to formulate and implement a tropical concept in the architecture of supporting facilities for Banyuwedang Hot Spring Tourism as part of a strategy to create sustainable tourism. This study uses the descriptive, qualitative, and interpretive methods through the interpretation of natural potentials in the Tourism Object Area with the adaptation of supporting facilities using the tropical concept approach. The result is the manifestation of tropical architecture in the aspects of orientation, shape, ventilation and lighting systems and material selection which is the tropical climate response of the Banyuwedang region and reduces the use of non-renewable energy sources.
\end{abstract}

Keywords: Banyuwedang Sustainable Architecture; Banyuwedang Tropical Architecture; Banyuwedang Tropical Concept; Banyuwedang Master Plan

\section{Pendahuluan}

Redesain fasilitas penunjang objek wisata Permandian Air Panas Banyuwedang merupakan tahun ke-2 dari perencanana awal (tahun 2018). Penataan tahap ke-1 (fasilitas utama) masterplan pada fasilitas: (1) kolam permandian umum (kolam terbuka); (2) bilik permandian privat; (3) bilik permandian pengobatan; (4) fasilitas locker, ruang bilas, dan toilet; (5) fasilitas jeti untuk mangrove tour dan fasilitas pendukungnya; (6) fasilitas loket karcis; dan (7) penataan fasilitas pedestrian dan sirkulasi pengunjung. Dalam redesain tersebut mempertimbangkan beberapa aspek yaitu: (1) konsep keberlanjutan dari potensi yang menjadi daya tarik wisata ini yaitu sumber mata air panas (kelebutan), Pura Mas Beji Banyuwedang, dan hutan mangrove; (2) keberlanjutan dari fungsi awal dari objek wisata ini yaitu rekreasi 
dan pengobatan; dan (3) konsep wisata yang "beretika" dan sesuai dengan tujuan wisata. Redesain fasilitas objek wisata Permandian Air Panas Banyuwedang memerlukan perencanaan desain yang menyeluruh, sehingga redesain fasilitas tahap pertama tidak cukup tanpa adanya perencanaan tahap selanjutnya yaitu fasilitas penunjang. Dan dalam perencanan awal (tahap ke-1) secara makro telah dibagi tata zonasinya antara fasilitas utama dan penunjang. Oleh karena itu, tahap ke-2 adalah kelanjutan dari perencanaan sebelumnya yang telah dikelompokan zonasinya.

Pariwisata yang berkonsep masyarakat baik itu masyarakat dalam kelompok desa setempat ataupun sadar wisata sedang berkembang di Bali. Hal tersebut sebagai upaya untuk mensikronkan potensi yang dimiliki dengan fasilitas yang disediakan serta kesadaran rasa memiliki potensi tersebut dalam mempertahankan keberlanjutannya. Seperti yang diungkapkan oleh Dewi (2013) yang menyatakan bahwa pariwisata berbasis masyarakat memiliki potensi utama yaitu alam, budaya dan manusia. Hal tersebut dapat dijumpai pada objekk wisata Permandian Air Panas Banyuwedang di Buleleng. Objek wisata ini berdiri pada tahun 1982 oleh pemerintah daerah Kabupaten Buleleng dan pada tahun 1984 diambil alih oleh Desa Adat Pejarakan yang dikelola oleh kelompok masyarakat sadar wisata. Adapun peta lokasi objek wisata ini disajikan pada gambar di bawah ini.

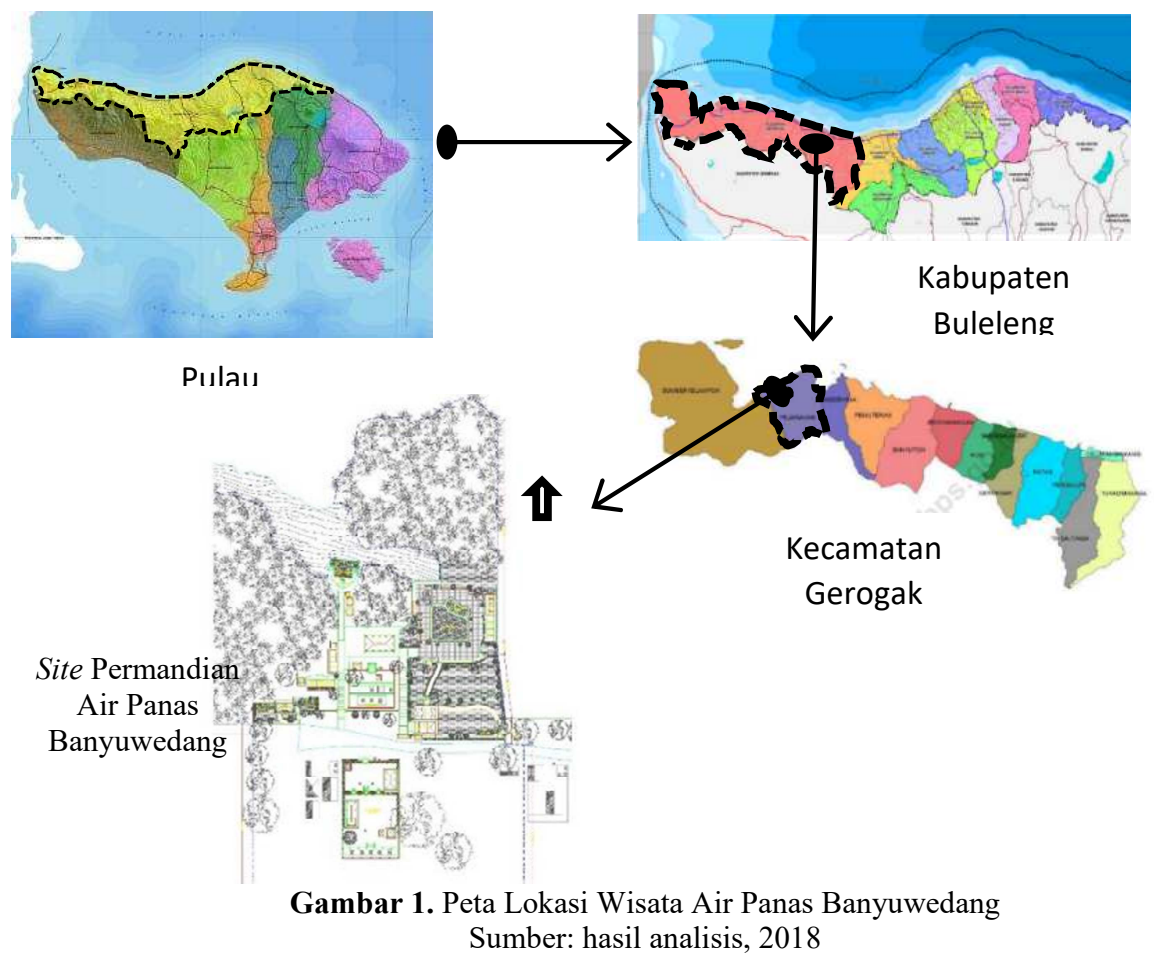

Wisata alam merupakan bentuk rekreasi yang memanfaatkan potensi sumberdaya alam dan memiliki manfaat baik kesehatan secara jasmani dan rohani juga mendapatkan pengetahuan dan pengalaman serta menumbuhkan rasa cinta terhadap lingkungan alam (Saragih, 1993). Potensi-potensi yang terdapat pada kawasan wisata permandian air panas Banyuwedang yaitu potensi alam dan spiritual. Potensi alam berupa (1) sumber mata air (kelebutan) panas yang terus mengalir dengan debit yang besar membentuk kolam permandian air panas, sumber mata 
air ini difungsikan untuk mengalirkan air ke kolam permandian terbuka maupun bilik-bilik; (2) pemandangan berupa view pantai Utara Bali dan hamparan hutan mangrove menambah keasrian kawasan wisata ini, pengunjung dapat menikmati pemandangan hijau sembari berendam; dan (3) udara yang masih segar dan alami yang tercipta oleh unsur-unsur hijau hutan mangrove dan juga tempat ini berada jauh dari permukiman penduduk yang ramai dan kota. Potensi yang dimiliki objek wisata ini yaitu potensi alam (air kelebutan dan hutan mangrove) dan potensi budaya yaitu Pura Mas Beji Banyuwedang dan Pura Dang Kahyangan Banyuwedang. Pemanfaatan potensi alam berupa air kelebutan melalui fasilitas permandian terbuka maupun tertutup untuk rekreasi maupun pengobatan. Fasilitas tersebut tidaklah cukup dalam mendukung kawasan ini sebagai daerah kunjungan wisatawan, sehingga diperlukan suatu fasilitas penunjang. Seperti yang diungkapkan oleh Yoeti (1996), wisatawan yang berkunjung ke objek wisata melakukan tiga hal yaitu something to do, something to see dan something to buy. Merujuk pada pernyataan tersebut, maka untuk mendukung fasilitas yang saling mendukung dan menyeluruh diperlukan suatu fasilitas penunjang wisata.

Saat ini fasilitas penunjang objek wisata Permandian Air Panas Banyuwedang berupa (1) tempat parkir yang ditata dengan baik; (2) warung-warung makan yang masih menyebar; dan (3) fasilitas ruang pengelola masih menjadi satu dengan zona utama. Berdasarkan wawancara dengan Ketua Pengelola Wisata Permandian Air Panas Banyuwedang terdapat beberapa hal yang akan direncanakan di kawasan tersebut. Hal-hal tersebut yaitu fasilitas gazebo, tempat parkir, art shop, tempat parkir pemedek Pura Dang Kahyangan Banyuwedang.

Redesain yang dilakukan yaitu membagi zone utama menjadi dua yaitu zona utama dan zona penunjang; redesain sirkulasi yang linier sehingga pengunjung dituntun untuk melewati setiap fasilitas yang disediakan; redesain tempat parkir pengunjung; redesain tempat parkir pemedek; redesain tempat makan (restaurant); redesain bangunan pengelola; redesain playground dan rekreasi; penambahan fasilitas lobby; penambahan fasilitas souvernir shop; penambahan fasilitas SPA dan penataan zonasi Pura Dangkahyangan Banyuwedang.

\section{Metode Pelaksanaan}

Metode pelaksanaan pada program ini adalah langkah-langkah dalam pelaksanaan solusi dan target capaian, yaitu:

\begin{tabular}{|c|c|}
\hline Target Capaian & Langkah-langkah Capaian \\
\hline \multicolumn{2}{|l|}{ A. Makro } \\
\hline $\begin{array}{l}\text { Tata zonasi pada dua zone tersebut } \\
\text { dalam bentuk gambar layout plan }\end{array}$ & 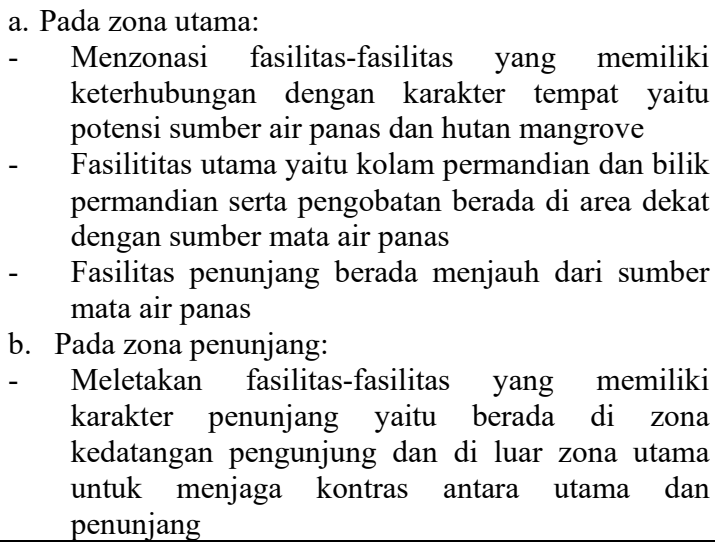 \\
\hline
\end{tabular}


- Mempertimbangkan aspek eksistensi pura dengan merencanakan ruang transisi antara pura dengan ruang rekreasi.

2 Tata Sirkulasi dalam bentuk gambar layout yang dilengkapi dengan arah pergerakan pengunjung serta gambar detail jalur pedestrian (gambar perspektif dan potongan) yang menjelaskan material yang dipergunakan, dimensi dan vegetasi yang digunakan.

\section{B. Mikro}

1 Gambar detail tempat parkir yaitu layout, perspektif, dan potongan serta spesifikasi material penyusunnya.

2 Gambar detail tempat parkir pemedek yaitu layout, perspektif, dan potongan serta spesifikasi material penyusunnya.

3 Gambar detail tempat makan yaitu layout, perspektif, dan potongan serta spesifikasi material penyusunnya.

4 Gambar detail bangunan pengelola yaitu layout, perspektif, dan potongan serta spesifikasi material penyusunnya.

5 Gambar detail ruang rekreasi yaitu layout, perspektif, dan potongan serta spesifikasi material penyusunnya. c. Zonasi tersebut (point a s/d b) di terjemahkan dalam gambar layout plan.

a. Sirkulasi kedatangan pengunjung dibedakan dengan sirkulasi kedatangan pemedek.

b. Sirkulasi diarahkan dari entrance utama kawasan menuju tempat parkir dan melewati setiap fasilitas penunjang yang disediakan.

c. Sirkulasi keluar atau balik melewati tempat yang telah dileawati dengan tujuan untuk memberikan kesempatan kepada pengunjung melewati tempat yang sama.

d. Untuk mencapai zona utama, pengunjung harus melewati zona penunjang.

a. Merumuskan program kebutuhan jumlah kendaraan pengunjung baik kendaraan mobil maupun sepeda motor.

b. Merumuskan spesifikasi pekerasan dan vegetasi peneduh tempat parkir.

c. Membuat gambar layout plan, tampak, potongan dan perspektif

a. Merumuskan program kebutuhan jumlah kendaraan pemedek baik kendaraan mobil maupun sepeda motor.

b. Merumuskan spesifikasi pekerasan dan vegetasi peneduh tempat parkir.

c. Membuat gambar layout plan, tampak, potongan dan perspektif

a. Merumuskan ruang atau fasilitas yang terdapat dalam restaurant yaitu ruang duduk, ruang kasir dan bar, dapur dan ruang penyimpanan makanan

b. Merumuskan kapasitas daya tampung pengunjung

c. Memperbesar luasan restaurant dari luasan saat ini

d. Merumuskan spesifikasi material dan struktur yang dipergunakan dalam perwujudan arsitekturnya

e. Membuat gambar layout plan, tampak bangunan, potongan dan perspektif

a. Merumuskan ruang-ruang kantor pengelola yaitu ruang ketua, ruang sekretaris, ruang bendahara dan ruang rapat serta ruang arsip

b. Merumuskan spesifikasi material dan struktur yang dipergunakan dalam perwujudan arsitekturnya

c. Membuat gambar layout plan, tampak bangunan, potongan dan perspektif

a. Merumuskan kapasitas pengguna ruang

b. Merumuskan spesifikasi elemen-elemen landscape

c. Membuat gambar layout plan, tampak, potongan dan perspektif 


\begin{tabular}{|c|c|c|}
\hline No & Target Capaian & Langkah-langkah Capaian \\
\hline 6 & $\begin{array}{l}\text { Gambar detail lobby yaitu layout, } \\
\text { perspektif, dan potongan serta } \\
\text { spesifikasi material penyusunnya. }\end{array}$ & $\begin{array}{l}\text { a. Merumuskan kapasitas lobby } \\
\text { b. Merumuskan ruang-ruang yang terdapat dalam } \\
\text { lobby } \\
\text { c. Merumuskan spesifikasi material dan struktur } \\
\text { yang dipergunakan dalam perwujudan } \\
\text { arsitekturnya } \\
\text { d. Membuat gambar layout plan, tampak bangunan, } \\
\text { potongan dan perspektif }\end{array}$ \\
\hline 7 & $\begin{array}{l}\text { Gambar detail fasilitas souvenir shop } \\
\text { yaitu layout, perspektif, dan potongan } \\
\text { serta spesifikasi material penyusunnya. }\end{array}$ & $\begin{array}{l}\text { a. Merumuskan kapasitas souvenir shop } \\
\text { b. Merumuskan ruang-ruang yang terdapat dalam } \\
\text { souvenir shop } \\
\text { c. Merumuskan spesifikasi material dan struktur } \\
\text { yang dipergunakan dalam perwujudan } \\
\text { arsitekturnya }\end{array}$ \\
\hline & & $\begin{array}{l}\text { d. Membuat gambar layout plan, tampak bangunan, } \\
\text { potongan dan perspektif }\end{array}$ \\
\hline 8 & $\begin{array}{l}\text { Gambar detail SPA yaitu layout, } \\
\text { perspektif, dan potongan serta } \\
\text { spesifikasi material penyusunnya. }\end{array}$ & $\begin{array}{l}\text { a. Merumuskan kapasitas SPA } \\
\text { b. Merumuskan ruang-ruang yang terdapat dalam } \\
\text { SPA }\end{array}$ \\
\hline & & $\begin{array}{l}\text { c. Merumuskan spesifikasi material dan struktur } \\
\text { yang dipergunakan dalam perwujudan } \\
\text { arsitekturnya }\end{array}$ \\
\hline & & $\begin{array}{l}\text { d. Membuat gambar layout plan, tampak bangunan, } \\
\text { potongan dan perspektif }\end{array}$ \\
\hline 9 & $\begin{array}{l}\text { Gambar Penataan area luar pura yaitu } \\
\text { layout, perspektif, dan potongan serta } \\
\text { spesifikasi material penyusunnya. }\end{array}$ & $\begin{array}{l}\text { a. Merumuskan jarak ruang transisi antara batas } \\
\text { tempat suci/pura dengan ruang rekreasi } \\
\text { b. Merumuskan vegetasi yang tepat untuk ruang } \\
\text { transisi tersebut } \\
\text { c. Membuat gambar layout plan, tampak, potongan } \\
\text { dan perspektif }\end{array}$ \\
\hline
\end{tabular}

\section{Hasil dan Pembahasan}

\subsection{Eksisting dan Permasalahan Tata Zonasi}

Eksisting Objek Wisata Permandian Air Panas Banyuwedang dapat dibagi menjadi:

a. Zona wisata permandian dan fasilitas penunjangnya yaitu (1) kolam permandian terbuka, (2) permandian pancuran, (3) bilik permandian, (4) bilik permandian pengobatan, (5) ruang bilas dan toilet, (6) locker pengunjung, (7) restauran, (8) warung-warung makan, (9) loket karcis, dan (10) tempat parkir.

b. Zona Ritual yaitu (1) Pura Mas Beji Banyuwedang dan (2) Pura Dang Kahyangan Banyuwedang.

c. Zona hutan mangrove

d. Zona Hotel Mimpi yang berada di sebelah timur objek wisata permandian ini. 


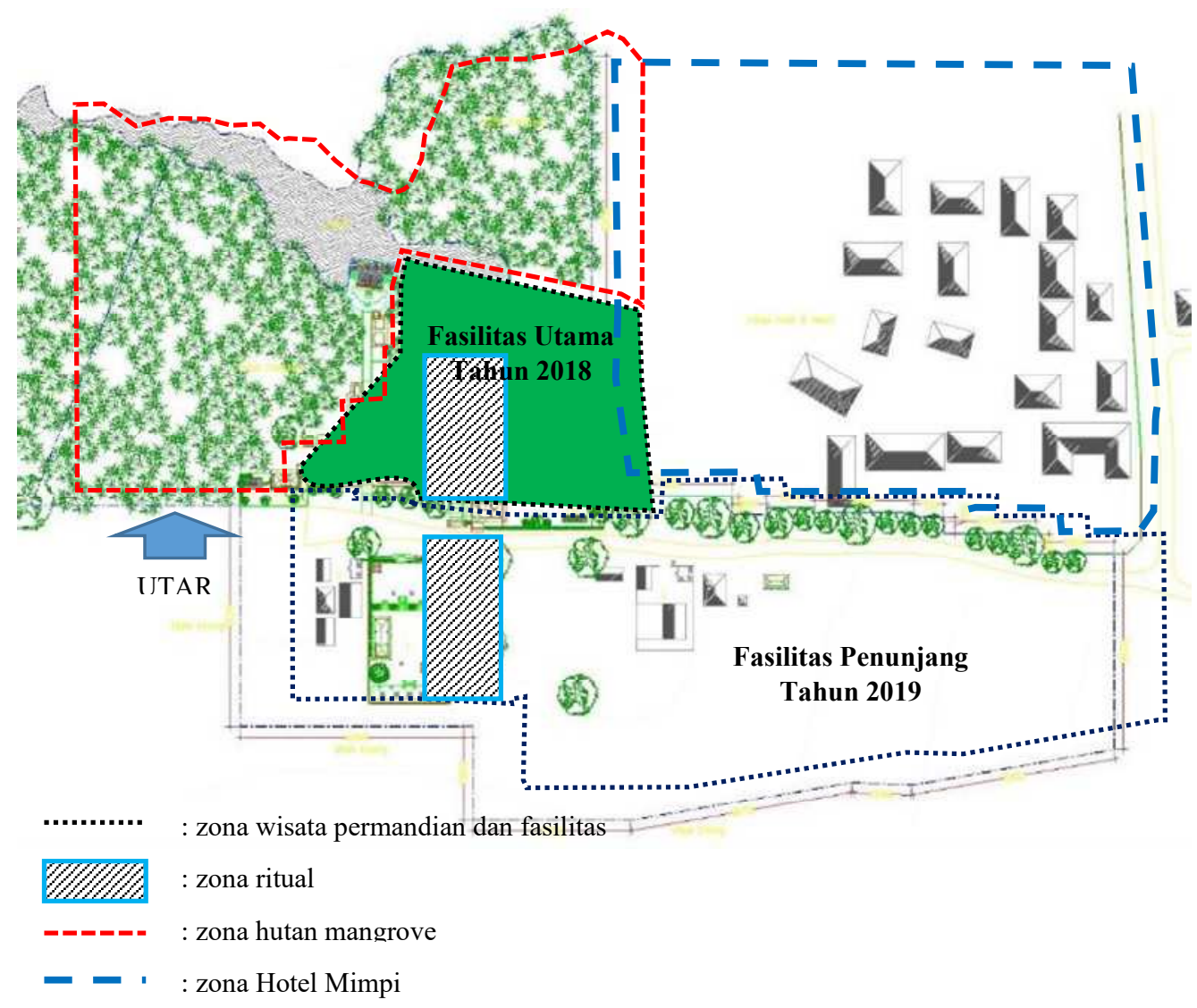

Gambar 2. Eksisting Objek Wisata Permandian Air Panas Banyuwedang Sumber: Penulis, 2019

Diperlukananya redesain pada zona ini didasari oleh:

a) Lahan ini merupakan lahan kosong yang dimiliki oleh Desa Banyuwedang. Fasilitas eksisting adalah warung makan, parkir liar dan arsitektur Pura Dang Kahyangan Banyuwedang.

b) Perencanaan selanjutnya dengan memanfaatkan lahan kosong tersebut yaitu (1) redesain tempat parkir pengunjung; (2) redesain tempat parkir pemedek; (3) redesain tempat makan (restaurant); (4) redesain bangunan pengelola; (5) redesain playground dan rekreasi; (6) penambahan fasilitas lobby; (7) penambahan fasilitas souvernir shop; (8) penambahan fasilitas SPA dan (9) penataan zonasi Pura Dang Kahyangan Banyuwedang.

c) Penataan tersebut berdasarkan pada diskusi dengan pihak pengelola wisata tersebut.

Gambaran eksisting Phase I dapat dilihat pada gambar di bawah ini. 

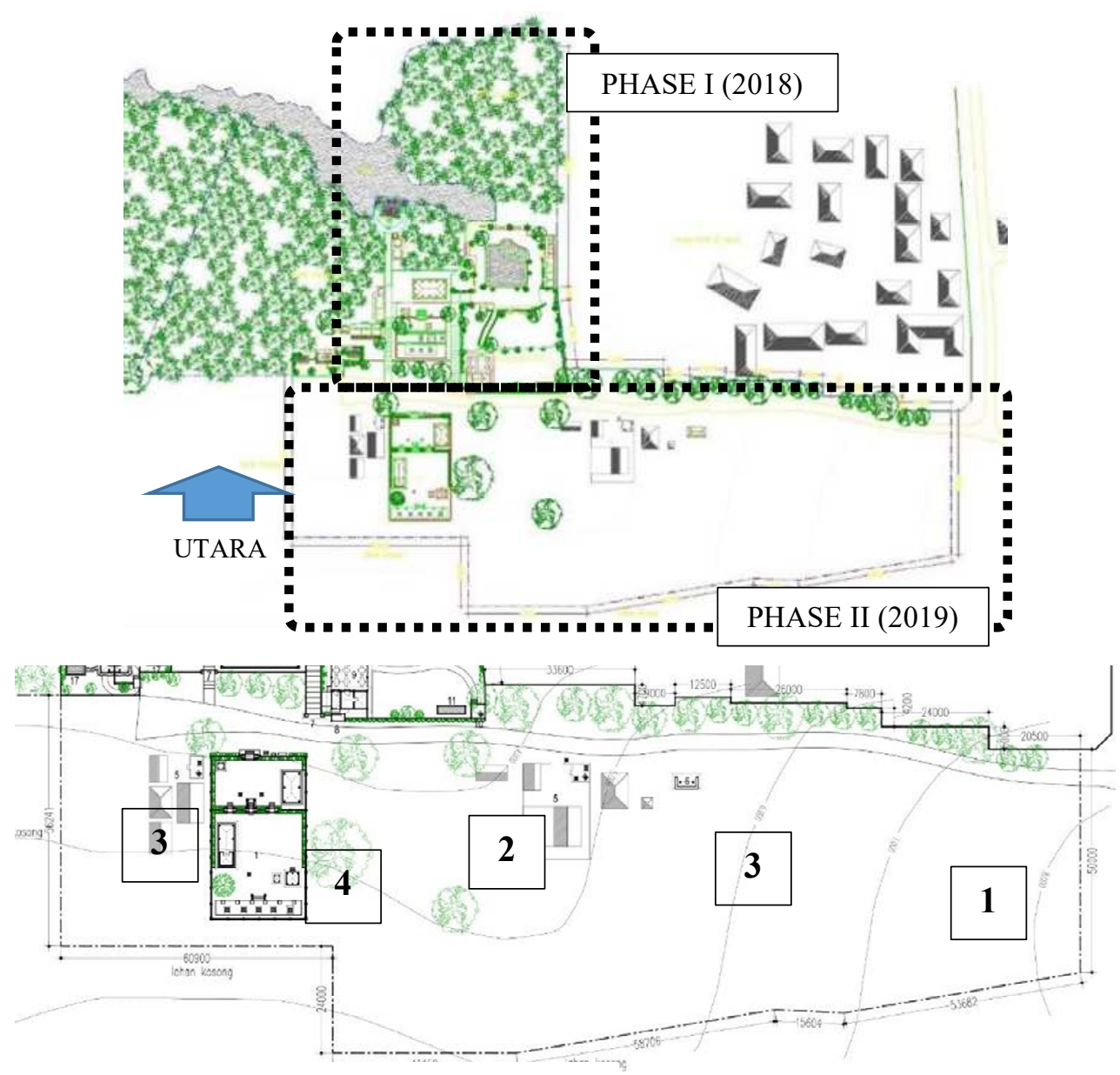

Keterangan:

1. Lahan Kosong

2. Tempat Parkir

3. Warung

4. Pura Dang Kahyangan Banyuwedang

Gambar 3. Pembagian Phase Redesain Sumber: Penulis, 2019

Gambar eksisting masing-masing peruntukan pada Gambar 7 di sajikan dalam gambar di bawah ini. 

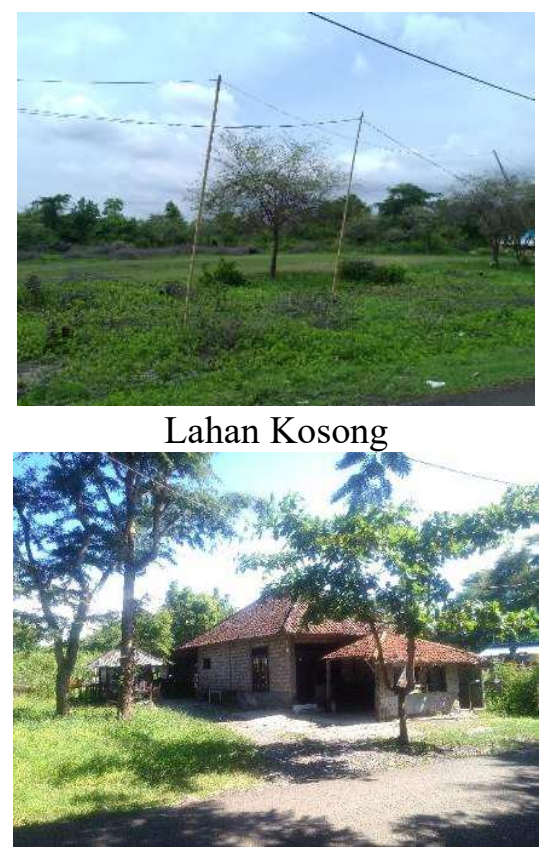

Warung

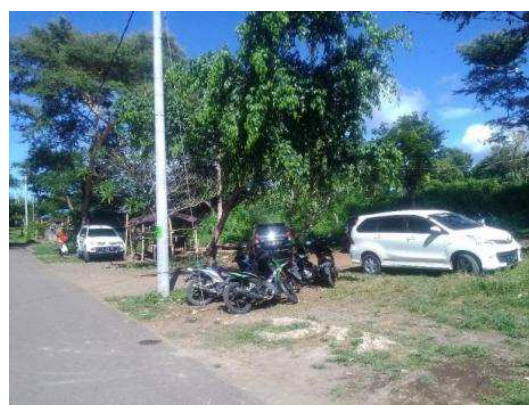

Tempat Parkir

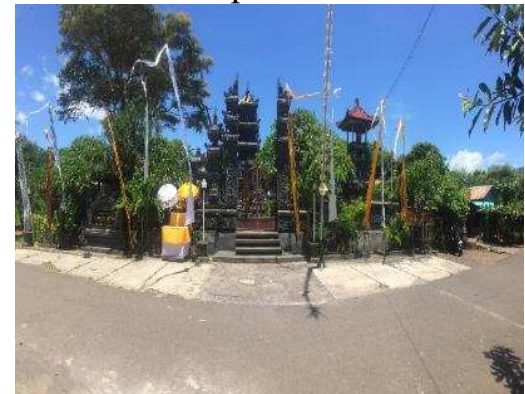

Pura Dang Kahyangan Banyuwedang

Gambar 4. Eksisting Objek Wisata Banyuwedang Sumber: Penulis, 2019

\subsection{Redesain Tata Layout}

\subsubsection{Tata Zonasi}

a) Tempat parkir dibagi menjadi dua yaitu parkir pengunjung dan parkir pemedek. Masingmasing parkir tersebut dizonasi berdasarkan jenis kendaraan yaitu sepeda motor dan kendaraan beroda empat. Tempat parkir untuk pengunjung berada di bagian ujung Timur dari site dimana tepat berada di bagian datangnya pengunjung. Tempat parkir pemedek berada di bagian barat dari Pura Dang Kahyangan Banyuwedang. Parkir pemedek ini memfasilitasi kegiatan-kegiatan, sehingga penataan ini memperhatikan aspek berlanjutan dari konteks yang telah terpelihara dengan baik yaitu kegiatan ritual.

b) Zona penerimaan berupa fasilitas lobby yang di dalamnya terdapat ruang resepsionis dan pembelian tiket, serta fasilitas penunjang berupa minimarket. Hal ini bertujuan untuk memfasilitasi pengunjung dalam memperoleh informasi atraksi wisata di tempat tersebut.

c) Fasilitas ruang pengelola berada pada satu zona dengan fasilitas utama dan berada pada zona penunjang. Fasilitas pengelola ini dilengkapi dengan ruang-ruang staff yang sesuai dengan bagian dan sub bagiannya. Tujuan perencanaan ini untuk memberikan fasilitas kontrol dan palayanan terhadap para pengunjung yang berkunjung ke tempat tersebut.

d) Restaurant berada di zona dekat dengan akses masuk ke fungsi utama. Hal ini bertujuan untuk efisiensi kegiatan pengunjung Pengunjung dilarang untuk membawa makanan ke dalam zona utama, untuk menjaga kebersihan fungsi utama.

e) Bagian depan dari restauran dilengkapi dengan play ground untuk fasilitas anak-anak.

f) Fasilitas penunjang lainnya yaitu SPA. Hal ini diperuntukkan bagi wisatawan yang memerlukan kondisi wellness setalah berwisata air panas.

g) Fasilitas menara untuk menikmati pemandangan hutan mangrove dan pantai utara Bali 


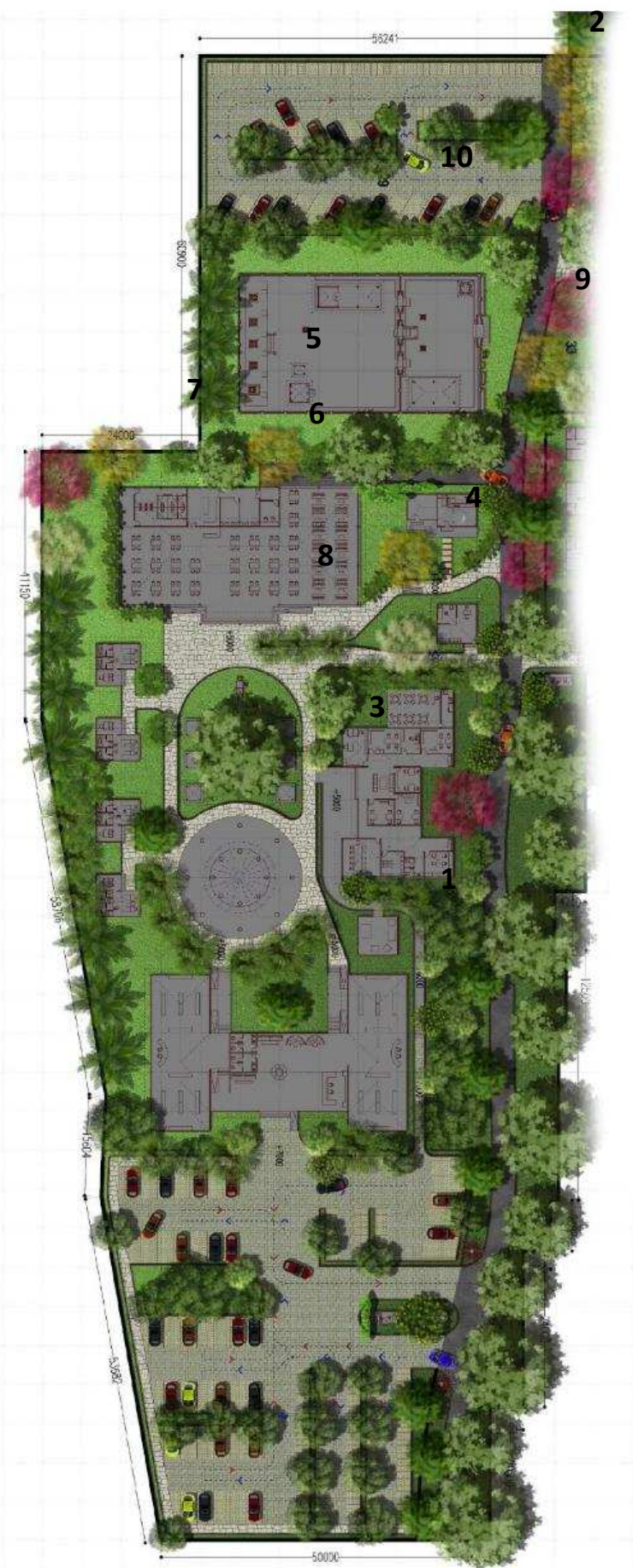

Gambar 5. Layout Keaesain Lona renunjang uøjek w1sata rermanaın Aır ranas Banyuwedang 


\subsubsection{Sistem Sirkulasi}

Sistem sirkulasi yang dipergunakan dalam redesain Objek Wisata Permandian Air Panas Banyuwedang adalah linier yaitu:

a) Sirkulasi regular yaitu sirkulasi pengunjung ke zona penunjang sebelum menuju zona utama. Pengunjung akan memasuki pintu utama untuk masuk ke are parkir untuk memarkir kendaraannya. Bagi wisatawan via agent umumnya di drop di depan lobby. Sebelum menuju fasilitas utama pengunjung harus melewati area lobby untuk membeli tiket dan mendaftarkan diri untuk kegiatan atraksi wisata permandian air panas. Selanjutnya pengunjung di arahkan melalui jalur pedestrian yang menuju ke fungsi utama. Sepanjang sirkulasi menuju fungsi utama, pengunjung disuguhi fasilitas restauran maupun mini market.

b) Sirkulasi Pemedek yaitu akses masyarakat yang ingin melakukan kegiatan ritual. Pemedek memiliki akses yang berbeda dengan pengunjung, pemedek dapat memarkir kendaraannya pada bagian Barat Pura Dang Kahyangan Banyuwedang. Dengan demikian tidak menimbulkan sirkulasi silang. Hal ini juga bertujuan agar kegiatan pariwisata tetap berjalan pada saat kegiatan ritual berlangsung.

c) Sirkulasi staff langsung menuju kantor pengelola setelah dari tempat parkir untuk melakukan registrasi kehadiran dan menuju ke pos masing-masing.

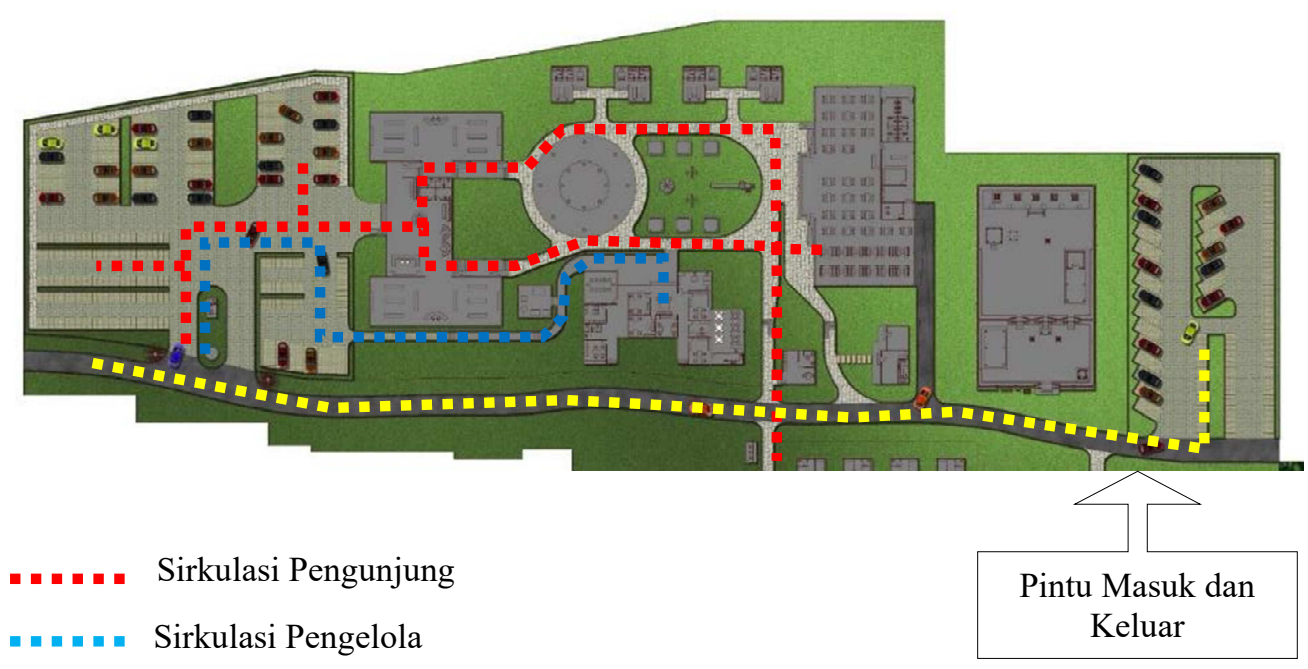

Sirkulasi Pemedek

Gambar 6. Konsep Sirkulasi Pengunjung, Pengelola dan Pemedek Sumber: Penulis, 2019

\subsubsection{Perspektif Kawasan}

Gambar perspektif kawasan menunjukan keterhubungan antar masa-masa bangunan dengan lingkungan sekitarnya dan elemen-elemen pembentuk ruang luar. 


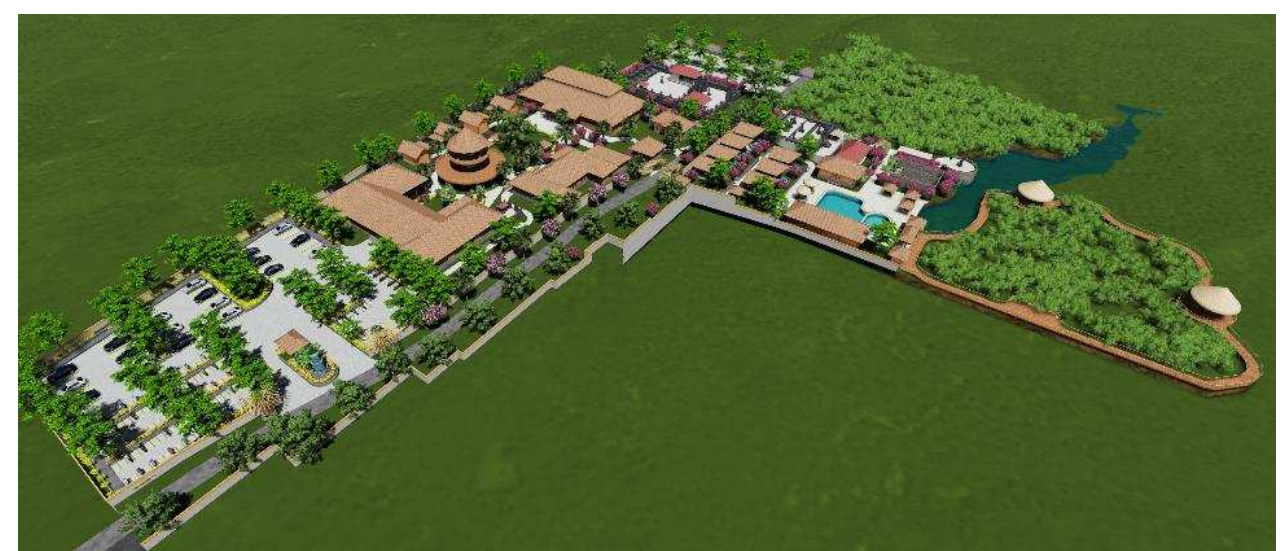

Gambar 7. Perspektif Objek Wisata Permandian Air Panas Banyuwedang Sumber: Penulis, 2019

\section{Kesimpulan}

- Konsep penataan objek wisata Permandian Air Panas Banyuwedang menggunakan pendekatan konsep keberlanjutan antara atraksi wisata melalui fasilitas-fasilitas yang telah direncanakan dengan konteks berupa kegiatan ritual di Pura Dang Kahyangan Banyuwedang.

- $\quad$ Konsep redesain dibagi menjadi dua phase yaitu Phase I dan II yang pelaksanaannya pada tahun yang berbeda, di mana Phase I pada tahun 2018 dan Phase II pada tahun 2019. Phase I meredesain fungsi utama yang dibagi menjadi dua zona yaitu zona rekreasi (fasilitas atraksi wisata) dan zona konservatif yaitu eksistensi arsitektur Pura Mas Beji Banyuwedang dan sumber mata air panas (kelebutan). Sedangkan Phase II berupa perencanaan fasilitas penunjang dari fungsi utama.

- Perwujudan konsep tersebut terwujud dari tampilan bangunan dengan menggunakan material-material alami seperti bambu, kayu dan batu alam (batu pilah dan batu kali). Hal ini bertujuan untuk membentuk ekspresi wujud arsitektur yang selaras atau bernuansa lingkungan setempat. Perwujudan yang lain juga melalui bukaan-bukaan ventilasi untuk menciptakan sirkulasi udara silang serta bukaan jendela yang bertujuan untuk memasukan cahaya matahari. Sehingga beban energy menjadi berkurang (low energy).

\section{References}

[1] Dewi, Luh Gede Leli Kusuma, 2013. Usaha Pemberdayaan Sosial Ekonomi Masyarakat Desa Beraban Dalam Pengelolaan Tanah Lot Secara Berkelanjutan. Sebuah Artikel dalam Jurnal "Analisis Pariwisata". Volume 13 Nomor 1 Tahun 2013. Fakultas Pariwisata Universitas Udayana.

[2] Saragih, Yansen Marthen Irianto. 2009. "Pengembangan Daya Tarik Wisata Aternatif di Pulau Mansimnam, Kecamatan ManokwariTimur, Papua Barat”. Tesis Program Megister Pariwisata. Universitas Udayana Denpasar.

[3] Yoeti, Oka A. 1996. Pengantar Ilmu Pariwisata Edisi Revisi. Bandung: Penerbit Angkasa. 